\title{
Assessment of the Bioactivity of Antibodies against $\beta$-Amyloid Peptide in vitro and in vivo
}

\author{
M. Hasan Mohajeri Meret N.M. Gaugler Julia Martinez Jay Tracy Hong Li \\ Arames Crameri Katrin Kuehnle M. Axel Wollmer Roger M. Nitsch
}

Division of Psychiatry Research, University of Zürich, Zürich, Switzerland

\section{Key Words}

Alzheimer's disease $\cdot$ Immunization · Microglia

\begin{abstract}
The accumulation of the $\beta$-amyloid peptide $(A \beta)$ is a central event in the pathogenesis of Alzheimer's disease (AD). $A \beta$ removal from the brain by immune therapy shows promising potential for the treatment of patients with $A D$, although the mechanisms of the antibody action are incompletely understood. In this study we compared the biological activities of antibodies raised against various $A \beta$ fragments for $A \beta$ reduction in vitro and in vivo. Antibodies against $A \beta$ enhanced the uptake of $A \beta_{42}$ aggregates up to 6 -fold by primary microglial cells in vitro. The kinetics of $A \beta_{42}$ uptake varied considerably among antibodies. Based on the activity to mediate $A \beta_{42}$ uptake by microglial cells, we identified a bioactive antibody that significantly reduced $A \beta_{42}$ levels in the brains of transgenic mice with neuronal expression of an AD-related mutated amyloid precursor protein. This effect depended on the epitopes recognized by the antibody. Our data suggest that the ability to facilitate $A \beta_{42}$ uptake by primary microglia cells in vitro can be used to predict the biological activity of the antibody by passive
\end{abstract}

\section{KARGER}

Fax + 41613061234

E-Mail karger@karger.ch

www. karger.com
(C) 2004 S. Karger AG, Basel

1660-2854/04/0015-0160\$21.00/0

Accessible online at:

www. karger.com/ndd immunization in vivo. This protocol may prove useful for the rapid validation of the activity of antibodies designed to be used in immune therapy of AD.

Copyright $@ 2004$ S. Karger AG, Basel

\section{Introduction}

Alzheimer's disease (AD), the most common cause of dementia, is an age-related neurodegenerative disorder that is characterized by progressive cognitive deficits, such as memory loss and a decline in mental abilities. An elevated abnormal level of the $\beta$-amyloid peptide $(A \beta)$ in the brain is the key step in the pathogenesis of $\mathrm{AD}$ [1-3]. $\mathrm{A} \beta$ is associated with the formation of neurofibrillary tangles $[4,5]$ with impaired synaptic functions and the loss of neurons. Therefore, a major emphasis of AD therapy has currently been on the removal of $A \beta$ from the affected brains.

Both active and passive immunization approaches were effective in reducing the brain $A \beta$ levels in human patients and in AD mouse models expressing AD-causing mutations of amyloid precursor protein (APP) resulting in a massive production of $A \beta$ and age-dependent amyloid plaque deposition [6-10]. In addition, anti-A $\beta$ immuniza-
M. Hasan Mohajeri

Division of Psychiatry Research, University of Zürich

August Forel Strasse 1

$\mathrm{CH}-8008$ Zürich (Switzerland)

Tel. +41 44634 8872, Fax +41 44634 8874, E-Mail mohajeri@bli.unizh.ch 

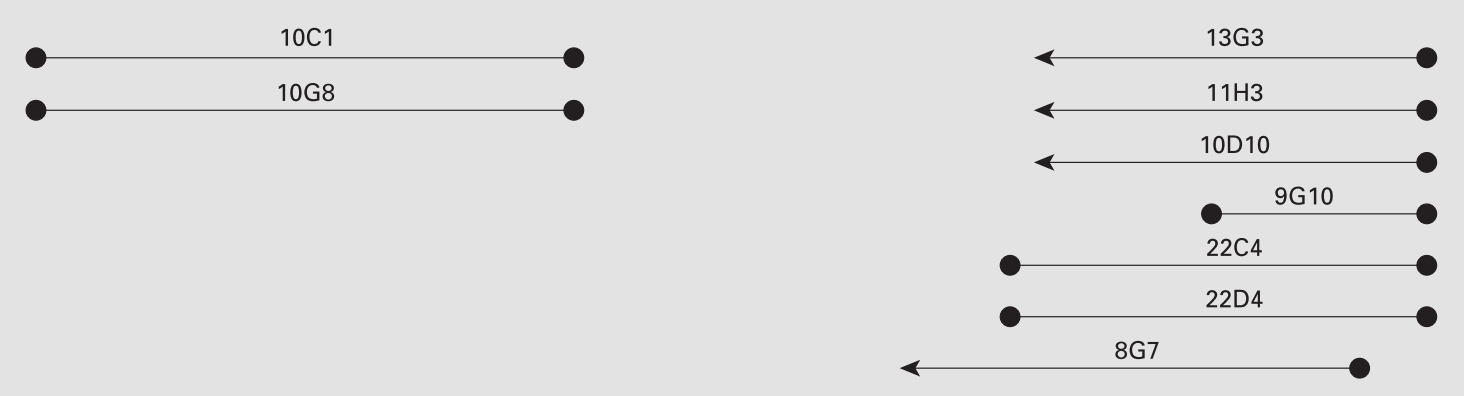

Fig. 1. Schematic presentation of different $A \beta$ fragments that were used to generate the monoclonal antibodies. Letters represent amino acids according to the single letter code. Numbers represent amino acid position within the peptide starting at the $\mathrm{N}$-terminus of the $\mathrm{A} \beta$ peptide. Bars correspond to the peptide that was used for immunization to generate the respective antibody. Balls define the ends of peptides used for immunization. Arrowheads indicate that the used peptides reached to the N-terminus of $\mathrm{A} \beta$.

tions exerted beneficial effects on cognitive performances of transgenic mouse models of $\mathrm{AD}[11,12]$ and in human subjects [13], providing the functional evidence for the validity of the $A \beta$ immune therapy. Furthermore, we have recently shown that anti-A $\beta$ immune therapy protected the neurons against apoptotic stimuli in an $\mathrm{AD}$ mouse model [10].

Mechanisms implicated in the reduction of brain $A \beta$ by antibodies may include acting as a peripheral sink to reduce cerebral $A \beta$ levels without entering the brain [7]. Alternatively, antibodies may penetrate into the brain, bind the $\mathrm{A} \beta$ and interfere with its aggregation $[8,14,15]$. Finally, upon opsonization of $A \beta$ by antibodies, the $A \beta /$ antibody complex is phagocytosed by brain microglial cells in both an Fc receptor-dependent and independent manner $[8,14,16]$.

Even though potent in reducing brain $A \beta$, immune therapy was shown to provoke aberrant autoimmune response such as meningoencephalitis or cerebral hemorrhages in human subjects or mice [17-19], indicating that under certain circumstances, immunization could lead to adverse side effects. Despite intense research and clinical interest in $A \beta$ immunization, the mechanisms by which antibodies result in clearing $A \beta$ from the brain are controversial. It is unclear why some antibodies enter the brain and clear $\mathrm{A} \beta$, whereas some similar antibodies are ineffective in the same system [8] and what the mechanisms of action of the proposed peripheral sink are. Moreover, the immunization protocol and the epitope of $A \beta$ chosen for immunization may affect the outcome of the active immunization [20-22]. Therefore, it is desirable to design a rapid method for predicting the bioactivity of anti-A $\beta$ antibodies by an in vitro test system. In this study the efficacy of microglia cells to take up and degrade $A \beta$ in vitro was used for an initial screening of anti-A $\beta$ antibodies active in vivo. We then verified the bioactivity of anti-A $\beta$ antibodies with a passive immunization protocol in vivo. We assessed the efficacy of these antibodies to reduce brain $A \beta_{42}$ levels and showed that the bioactivity of antibodies against $A \beta$ is dependent on the epitope recognized by these antibodies.

\section{Material and Methods}

\section{Hybridoma Cultures and Antibody Production}

The monoclonal antibodies were raised against full-length $\mathrm{A} \beta$ peptide or its fragments (fig. 1) and the produced antibodies were tested to recognize the respective peptides and the full-length $\mathrm{A} \beta$ peptide by Western blotting. Hybridoma clones producing antibodies against various fragments of the $\mathrm{A} \beta$ peptide were cultured in OPTIMEM 1 (Gibco) containing 10\% heat-inactivated fetal bovine serum (FBS) and penicillin/streptomycin. The FBS concentration was gradually reduced to a final concentration of $0.1 \%$. Conditioned media were collected and the antibodies were purified via protein A columns (Mo Bi Tech). In brief, the protein A column was washed with $15 \mathrm{ml}$ of $1 \times$ binding buffer ( $1 \mathrm{M}$ glycine, $0.15 \mathrm{M} \mathrm{NaCl}, \mathrm{pH}=8.6)$ at a flow rate of $1 \mathrm{ml} / \mathrm{min}$. Conditioned media were mixed 1:1 with $2 \times$ binding buffer and pumped through the column at $1 \mathrm{ml} / \mathrm{min}$ at room temperature. Columns were then washed with $30 \mathrm{ml}$ of $1 \times$ binding buffer and antibodies were eluted with elution buffer $(0.1 \mathrm{M}$ citrate, 
pH 5.5 and $\mathrm{pH}$ 3), desalted and neutralized by dialysis against PBS overnight. The subclass of purified anti-A $\beta$ antibodies was determined using the monoclonal antibody isotyping kit (Boehringer Mannheim) according to the supplier's protocol.

\section{Primary Microglia Cultures}

Primary cultures of mixed glia were prepared from newborn C57BL/6J mice. Meninges, olfactory bulb and hippocampus were removed from brain hemispheres. Neocortical tissue was dissociated by incubation with dissociation solution $(0.02 \%$ EDTA, $0.24 \%$ HEPES, $6.6 \%$ trypsin and $0.8 \%$ DNase I in DMEM) for $15 \mathrm{~min}$ at $37^{\circ} \mathrm{C}$ followed by an incubation in DMEM (Gibco) containing $10 \%$ FBS and $1.6 \%$ DNase I for $15 \mathrm{~min}$ at $37^{\circ} \mathrm{C}$ and subsequent triturating by a set of fire-polished glass pipettes of descending diameter. Tissue homogenates were passed through a nylon mesh of $24 \mu \mathrm{m}$ pore size (Millipore). $5 \times 10^{6}$ cells were plated per T25 flasks and grown in DMEM medium containing $10 \%$ FBS to confluency within 10 days. Culture medium was changed after $24 \mathrm{~h}$ and every 3 days thereafter. After 14 days microglial cells started to proliferate and floated at the surface of the medium. Loosely attached cells could be mobilized by gentle shaking of the culture. Microglial cells were harvested by aspiration of the supernatant fluid, centrifuged at $100 \mathrm{~g}$ for $5 \mathrm{~min}$ and resuspended in culture medium. For immunocytochemistry, cells were plated on glass coverslips coated with poly- $D$-lysine (30-70 kD, Sigma) at a density of 10,000 cells $/ \mathrm{cm}^{2}$ (low-density cultures). For quantification of $\mathrm{A} \beta$ uptake, cells were cultured in 96-well plates at a density of 100,000 cells/well (high-density cultures). Ten minutes after plating, the microglial cells were adherent and nonadherent cells were eliminated by gently rinsing the cultures with medium. Lectin immunostaining identified more than $95 \%$ of cells in these cultures as microglial cells.

\section{In vitro Studies}

Synthetic human $A \beta_{42}(1 \mathrm{mg} / \mathrm{ml}$, Bachem) was fibrillized in PBS as described [23]. For qualitative evaluation of $A \beta_{42}$ uptake in microglial cells by immunohistochemistry, the $A \beta_{42}$ stock was diluted 1:10 with anti-A $\beta$ antibody solutions $(300 \mu \mathrm{g} / \mathrm{ml})$ and incubated overnight at $4{ }^{\circ} \mathrm{C}$ in a rotary shaker at $5 \mathrm{rpm}$ to generate an $\mathrm{A} \beta_{42} /$ antibody complex. For quantitative determination of microglial uptake by ELISA, $A \beta_{42}$ stock solution was mixed in a 1:1 ratio with the antibody solutions to generate the $A \beta_{42} /$ antibody complex.

$A \beta_{42}$ /antibody complexes were diluted 20 or 33 times in culture medium before incubation with low- or high-density cultures, respectively. Three days later the low-density cultures were washed with PBS, fixed with ice-cold methanol for $10 \mathrm{~min}$ and subjected to immunocytochemistry. High-density cultures were incubated with $A \beta_{42}$ complexes for 2,24 or $72 \mathrm{~h}$. After several washes, the cultures were then subjected to formic acid extraction and ELISA measurement of cellular $A \beta$. Control cultures were incubated with fibrillar $A \beta_{42}$ alone. To control for unspecific binding of complexes to the culture dish, complexes were also incubated in cell-free wells.

\section{A $\beta$ Extraction from Microglia Cultures}

High-density cultures were incubated with $A \beta_{42} /$ antibody complex or fibrillar $A \beta_{42}$ alone for 2, 24 and $72 \mathrm{~h}$. Cells were washed 3 times with PBS, lysed with $70 \%$ formic acid and the resulting extracts were neutralized by addition of 20 -fold volume of $1 M$ Trizma base. Internalized microglial $\mathrm{A} \beta$ content was quantified by ELISA as described $[10,23]$. At least three wells were treated with each antibody in each experiment.

\section{Immunostaining and Western Blotting}

After fixation, cultures were washed 3 times with PBS for $5 \mathrm{~min}$ and blocked in $10 \%$ goat serum for $30 \mathrm{~min}$ before incubation with Griffonia simplicifolia isolectin B4 $(2 \mu \mathrm{g} / \mathrm{ml}$, Vector $)$ in PBS containing $0.1 \%$ Triton X-100 for $48 \mathrm{~h}$ at $4{ }^{\circ} \mathrm{C}$. After 3 washes with PBS, cells were incubated with anti-lectin (Vector) and anti-A $\beta$ antibodies (4G8, Signet) in PBS containing $1 \%$ goat serum and $0.1 \%$ Triton $\mathrm{X}-100$ for $2 \mathrm{~h}$ at room temperature. For double staining against $\mathrm{A} \beta$ and lysosomes, the 4G8 antibody was combined with the anti-lysosomal-associated membrane protein-1 (LAMP-1) antibody (SouthernBiotech). In addition, Iba1 $[24,25]$ antibody was also used to assess microglia activation.

For analysis of APP processing and microglia activation by Western blotting, mice were anesthetized and perfused transcardially with ice-cold PBS. Frontal parts of the brains reaching from the stereotaxic coordinates interaural 6-5 were homogenized and subjected to Western blotting as described $[10,23]$. The remaining parts of the brains were fixed in $4 \%$ paraformaldehyde, washed several times in PBS and 35- $\mu \mathrm{m}$ frontal sections were prepared. After electrophoresis, blots were probed with 6E10 (Signet) and C-terminal APP (Sigma) antibodies to study possible alterations of APP processing due to antibody treatments, as well as Iba1 antibody for quantification of the activation status of microglia. Blots were stripped and probed for $\beta$-actin (Abcam) as a loading control [10]. Similarly, to test whether the monoclonal anti-A $\beta$ antibodies recognize transgenically expressed $A \beta$, similar amounts of a brain homogenate of an agematched SwAPP mouse were loaded onto the gel and probed with the monoclonal anti-A $\beta$ antibodies $(50 \mu \mathrm{g} / \mathrm{ml})$.

\section{Passive Immunization}

Transgenic mice with neuronal expression of the Swedish double mutation of APP (SwAPP mice) were bred and housed as described $[10,23]$. SwAPP mice were passively immunized by intravenous (i.v.) injections of several monoclonal anti-A $\beta$ antibodies. Each mouse was given four injections into the tail vein of $9 \mathrm{mg}$ antibody $/ \mathrm{kg}$ body weight at intervals of 5 days beginning at $6-7$ weeks of age $(n=$ 3-4 per group) [10]. Mice were sacrificed the day after the last antibody injection. Titers of anti-A $\beta$ antibodies and levels of $A \beta_{42}$ were measured in sera and compared to the corresponding values prior to the injections as previously described $[10,23]$, and correlated to $A \beta_{42}$ levels in the brains of the same mice. The control group comprised untreated age-matched SwAPP littermates $(n=4)$.

\section{Statistical Analysis}

Data were collected by investigators blinded to the experimental setup and were analyzed by the nonparametric Mann-Whitney U test. In all graphs, means \pm SEM are shown.

\section{Results}

\section{Microglial Cells Internalized Fibrillar $A \beta_{42}$ and $A \beta_{42} /$ Antibody Microaggregates in vitro}

To discriminate between antibody-dependent and antibody-independent uptake of $A \beta_{42}$ by microglial cells in vitro, primary microglial cells were incubated for up to 3 days with either fibrillar $A \beta_{42}$ alone or with $A \beta_{42} /$ antibody 

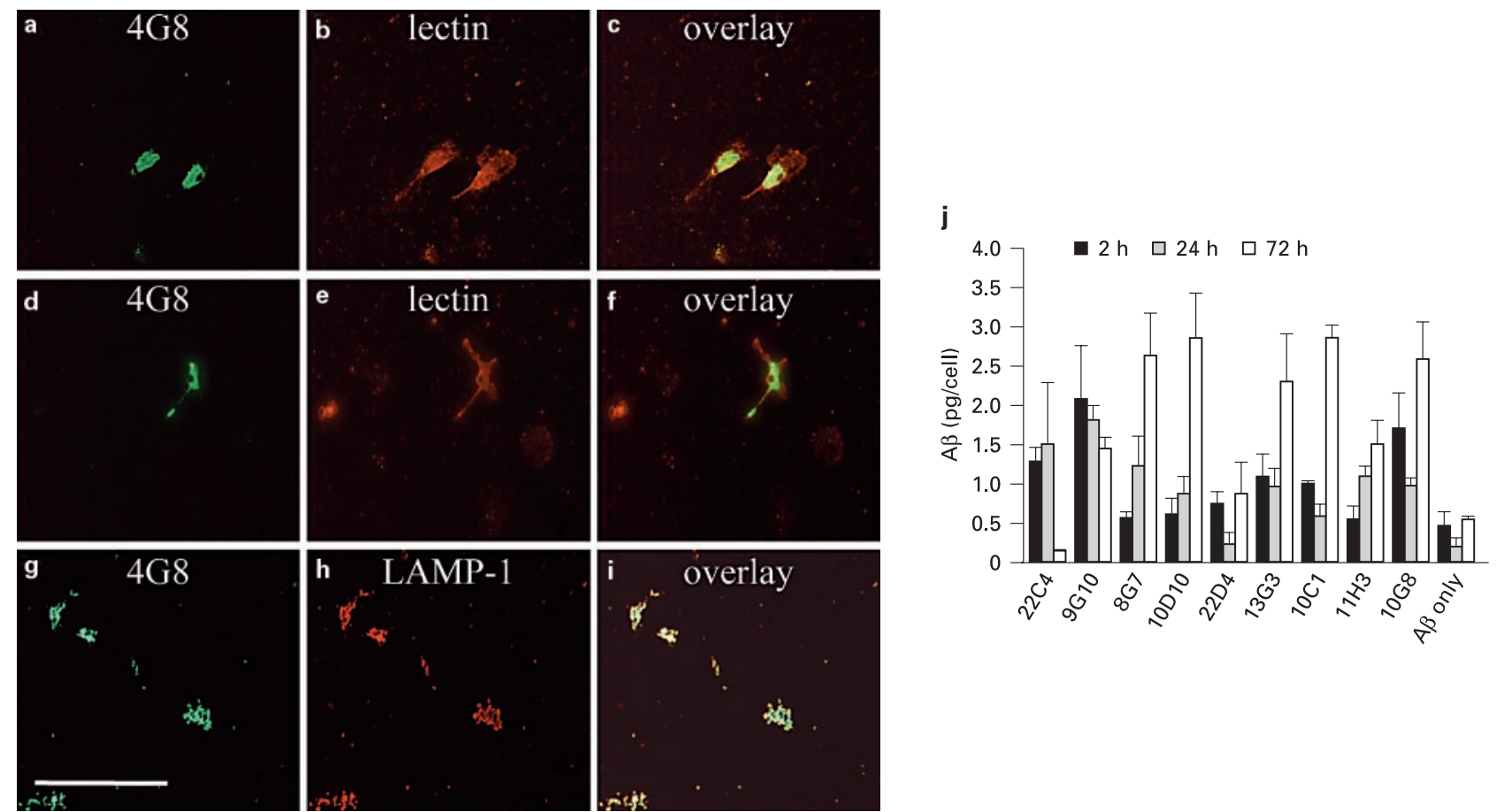

Fig. 2. Accumulation and phagolysosomal localization of $A \beta_{42}$ by microglial cells. $A \beta_{42}$ alone (a-c) or $A \beta_{42} /$ antibody complex $(\mathbf{d}-\mathbf{i})$ were incubated with low-density cultures of primary microglial cells for $24 \mathrm{~h}$ and stained with antibodies against $\mathrm{A} \beta(4 \mathrm{G} 8, \mathbf{a}, \mathbf{d}, \mathbf{g})$ and lectin $(\mathbf{b}, \mathbf{e})$ to identify $\mathrm{A} \beta$ and the microglial cells, respectively. Microglial cells took up $A \beta_{42}$ both if it was applied as a complex with specific antibodies (d-f, $\mathbf{g}-\mathbf{i})$ or if applied alone (a-c). 4G8-immunoreactive material was accumulated in granular structures around the nucleus of microglial cells (a, $\mathbf{d}$ and $\mathbf{c}, \mathbf{f}$ overlay). In addition, cultures were doubly immunostained against $\mathrm{A} \beta$ and a lysosomal marker (LAMP-1). LAMP-1-reactive structures (h) and A $\beta$-positive structures $(\mathbf{g})$ showed a broad overlap (i), indicating phagolysosomal localization of $A \beta$ in microglial cells. $\mathbf{j}$ Quantification and kinetics of $\mathrm{A} \beta_{42}$ uptake by microglial cells. Microglial $\mathrm{A} \beta_{42}$ levels extracted by formic acid depended on the antibody used and on the incubation time. Measurements were made at time points 2, 24 and $72 \mathrm{~h}$ and represented as absolute cellular $\mathrm{A} \beta_{42}$ content. Scale $100 \mu \mathrm{m}$. complex of $A \beta_{42}$ with various monoclonal anti-A $\beta$ antibodies generated against the entire $A \beta$ peptide or its $N$ versus $\mathrm{C}$ terminal fragments (fig. 1). Immunoreactivity with $G$. simplicifolia isolectin B4 identified the cultured microglia. Cultures were examined by double immunostaining with microglial and $A \beta$ markers. $A \beta$ immunoreactivity was associated with microglial cells, indicating that microglial cells take up fibrillar $A \beta_{42}$ and the $A \beta_{42}$ /antibody complexes. Microglial cells accumulated $\mathrm{A} \beta_{42}$ both when fibrils were applied alone (fig. 2a-c) and as a complex (fig. $2 \mathrm{~d}-\mathrm{i}$ ). To further exclude that $\mathrm{A} \beta_{42}$ is only absorbed to the surface of microglial cells but not internalized, cultures were double-stained for $\mathrm{A} \beta$ and a lysosomal antigen (LAMP-1). A $\beta$ and LAMP-1 immunofluorescence showed a broad overlap (fig. $2 \mathrm{~g}-\mathrm{i}$ ), indicating that double- stained structures correspond to phagolysosomes containing $A \beta$.

To compare the efficacy of the purified antibodies to mediate uptake of fibrillar $A \beta_{42}$ by microglia, microgliaassociated $\mathrm{A} \beta_{42}$ was quantified by ELISA in cell extracts (fig. 2j). These measurements revealed a basal antibodyindependent uptake of $A \beta_{42}$ by microglial cells. Up to 6fold higher $A \beta_{42}$ levels were found in microglia cells that were incubated with the $A \beta_{42}$ /antibody complex when compared to incubation of the cells with $A \beta$ alone (fig. $2 \mathrm{j}$ ). Both efficacy and kinetics of $A \beta_{42}$ uptake by microglia cells differed between antibodies used for the formation of $A \beta_{42}$ /antibody complexes. Maximum $A \beta_{42}$ uptake was reached after 3 days for most of the complexes, except for $22 \mathrm{C} 4$ where the amount of cellular $A \beta_{42}$ was highest at 

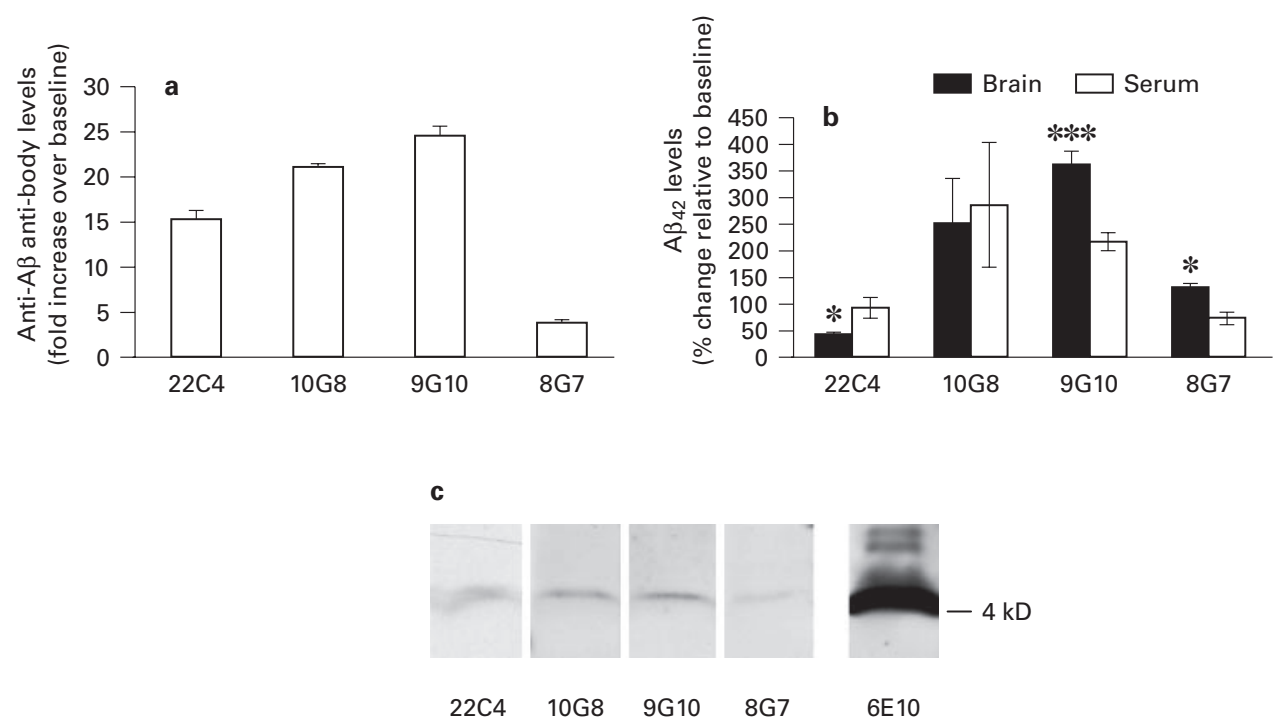

Fig. 3. Passive immunization of SwAPP mice. a Elevated levels of anti-A $\beta$ antibody titers were measured at the time of perfusion in sera of all SwAPP mice injected peripherally with identical amounts of purified antibodies. The values are expressed as fold increase, relative to corresponding serum antibody levels of 23 aged-matched untreated SwAPP mice that was set as $100 \%$. b A $\beta_{42}$ concentrations in brain homogenates and sera of SwAPP mice injected peripherally with purified anti-A $\beta$ antibodies. The values are expressed in percent relative to a $100 \%$ baseline of the corresponding values obtained from averaging readings from a control group of 4 noninjected SwAPP littermates $\left(* \mathrm{p} \leq 0.05,{ }^{* * *} \mathrm{p} \leq 0.001\right)$. Note that no group revealed a significant change of the $A \beta_{42}$ concentrations in serum relative to the baseline. c All anti-A $\beta$ antibodies used in the immunization study recognized the human transgenic $A \beta$ expressed in SwAPP brains. The same SwAPP brain homogenate was loaded onto all lanes and the antibody $6 \mathrm{E} 10$ served as positive control.
24 h. For $22 \mathrm{C} 4$ clone, intracellular $A \beta_{42}$ levels reached basal levels after 3 days, indicative of a rapid uptake of $A \beta_{42}$ and its degradation between 1 and 3 days (fig. $2 \mathrm{j}$ ). While $8 \mathrm{G} 7$ mediated a constant increase of microglial $\mathrm{A} \beta_{42}$ over time, 22D4 was completely ineffective in facilitating $A \beta_{42}$ uptake. Thus, this experimental system allows for quantifying the efficacy of antibodies to mediate $A \beta_{42}$ uptake in vitro.

To determine whether the varying effects mediated by different antibodies to take up and degrade $A \beta_{42}$ by microglia cells may be related to different subtypes of $\mathrm{IgG}$, we isotyped the anti-A $\beta$ antibodies used in this study. All antibodies were identified as IgG1-containing $\kappa$ light chains, thus eliminating the possibility that different antibody subtypes may be responsible for the observed effects.

\section{In vivo Activity of Anti-A $\beta$ Antibodies}

The effectiveness of anti-A $\beta$ antibodies to reduce the $\mathrm{A} \beta$ levels in vivo was studied by i.v. injection of purified antibodies into the tail vein of SwAPP mice. Hybridoma clones were selected on the basis of their varying kinetics to mediate $A \beta$ uptake by primary microglia in vitro and attention was paid to choose clones generated against defined fragments of $A \beta$. In addition, one chosen clone recognized only $A \beta_{40}$ but not the $A \beta_{42}$ molecule.

Serum anti-A $\beta$ antibody levels were assessed by analysis of the blood samples taken at the time of perfusion and were compared to baseline antibody levels of 23 untreated age-matched SwAPP littermates (fig. 3a). Antibody titers of the individuals receiving i.v. antibody injections in one group revealed little variation. This finding was expected because a standard amount of purified antibody (adjusted to the body weight of each mouse) was peripherally administrated. Strikingly, even though the same amount of antibody was injected for all groups, the level of antibody detectable in serum was lower for $8 \mathrm{G} 7$-injected mice (fig. 3a), probably due to a faster turnover of this antibody in vivo. 
Finally, $A \beta_{42}$ concentrations in sera and brains of SwAPP mice, peripherally injected with purified antibodies, were assessed (fig. 3b). The injection of the antibody $22 \mathrm{C} 4$ caused a $55 \%$ reduction of brain $\mathrm{A} \beta_{42}$ levels $(\mathrm{p} \leq 0.05)$, while mice injected with $8 \mathrm{G} 7$ and $9 \mathrm{G} 10$ antibodies showed an unexpected significant elevation of cerebral $A \beta_{42}$ levels. The elevation of $A \beta_{42}$ levels after 10G8 injections did not reach statistical significance (fig. 3b). The levels of $A \beta_{42}$ correlated significantly in the serum and brains of treated mice (Pearson-Spearman correlation coefficient $=0.646, \mathrm{p} \leq 0.05$ ). For mice injected with the $22 \mathrm{C} 4$ antibody, a strong negative correlation was found between the anti-A $\beta$ antibody levels in serum and the $\mathrm{A} \beta_{42}$ concentrations in the brain (correlation coefficient: $-0.98, p \leq 0.01$ ). In addition, i.v. antibody injections did not change serum $A \beta_{42}$ levels in any group (fig. 3b). Moreover, Western blot analysis on SwAPP brain homogenates revealed that all antibodies recognized the $A \beta$ expressed in these brains (fig. $3 c$ ).

When compared to untreated brains, no consistent change in APP processing or microglia activation could be detected by Western blotting in brains of mice as a result of passive immunization (not shown).

\section{Discussion}

The aim of this study was to set up a system to compare the ability of different monoclonal anti-A $\beta$ antibodies, raised against different fragments of the $A \beta$ peptide, to mediate the uptake and degradation of $A \beta_{42}$ in vitro and in vivo. The results of this study show that antibodymediated $A \beta_{42}$ uptake by primary microglia cells in vitro can be used as a measure to predict the bioactivity of anti$\mathrm{A} \beta$ antibodies in vivo.

To compare the efficacy at which $\mathrm{A} \beta_{42}$ was taken up by the microglial cells when applied as a complex with various antibodies, internalized $\mathrm{A} \beta_{42}$ in microglial cells was quantified by ELISA. Different antibodies varied in their activity to mediate uptake of $A \beta$, both for the overall amount of $A \beta_{42}$ taken up and also for the kinetics of this uptake, indicating that the degradation of $A \beta_{42}$ is affected by the complexing antibody. These variations cannot be explained by differences in antibody subclasses, which are known to differ in their opsonization capacities because all antibodies included in this test belonged to the same subclass.

Active and passive immunization against fibrillar $\mathrm{A} \beta$ have proven to be powerful tools in reducing or preventing amyloid pathology in transgenic mice overexpressing human mutant APP $[7-9,11,12,15,21]$ and in human subjects [6]. It is, however, not yet understood why some anti- $A \beta$ antibodies are potent in removing $A \beta$ from the brain, whereas others are ineffective, even though they recognize $A \beta$ in vitro [8].

Other than by mediating microglial uptake of $A \beta$, antibodies against the peptide may also clear $A \beta$ from the $\mathrm{CNS}$ and plasma by inducing a shift in the equilibrium between the two compartments and facilitate $A \beta$ flux from a central to a peripheral compartment $[7,26]$. Moreover, an efficient receptor-mediated bidirectional transport mechanisms for $A \beta$ was shown at the blood-brain barrier that transports the peptide from the CNS to plasma, as well as from plasma to the CNS [26].

Our data are in agreement with studies showing a scavenger receptor-mediated basal $A \beta$ uptake by microglial cells without the action of antibodies and that this uptake is increased by anti-A $\beta$ antibodies [27, 28]. In a similar study, however, an anti- $\mathrm{A} \beta$ antibody increased $\mathrm{A} \beta$ uptake solely 1.5-fold [27], whereas we observed an up to 6-fold increase of $A \beta$ uptake by microglial cells after antibody treatment. The reasons for the varying capacity of the antibodies to facilitate $A \beta$ uptake may be found in the epitope recognized by the antibody (17-24 on A $\beta$ peptide) and in the antibody subtypes (IgG2) used in that study [27]. Furthermore, passive immunization with an antibody against $A \beta$ of the $\mathrm{IgG} 1$ subtype was recently shown to increase the $\mathrm{Fc} \gamma$ receptor expression on microglia in SwAPP mice and led to a reduction of amyloid pathology [29], suggesting an active role of antibodies to promote the clearance of $A \beta$ by microglial cells in vivo.

We chose young SwAPP mice without plaque pathology to assess antibody-mediated changes in soluble $A \beta$, because concentrations of the soluble $A \beta$ correlate considerably with the degree of cognitive impairment in $\mathrm{AD}$ patients [30, 31]. Moreover, we were most interested in $\mathrm{A} \beta_{42}$ because it represents the predominant amyloidogenic $A \beta$ species and its levels are massively increased in the progression of pathology in both AD patients and APP transgenic mouse models.

At the time of perfusion, high levels of anti-A $\beta$ antibody titers were measured in all mice injected peripherally with purified antibodies. The antibody level in sera of mice injected with 8G7 was markedly lower, even though exactly the same amounts of antibody had been injected. We postulate that these differences are probably attributable to a variability in the biological activity or antibody turnover in vivo. When compared to untreated SwAPP littermates (baseline), brain $\mathrm{A} \beta_{42}$ concentrations were significantly lower in mice treated with $22 \mathrm{C} 4$ and unex- 
pectedly increased in mice injected with antibodies $8 \mathrm{G} 7$ and 9G10. We could not assess whether the antibodies were able to effectively bind soluble $A \beta$ in the brain. All antibodies used here, however, could recognize $A \beta$ in SwAPP brain homogenates on Western blot level and all have facilitated $\mathrm{Fc}$ receptor-mediated microglial uptake of fibrillar $A \beta_{42}$ in vitro, suggesting that they could interact with the $\mathrm{A} \beta$ peptide.

The absence of an effect on the brain levels of soluble $\mathrm{A} \beta_{42}$ can be explained by the failure of the antibodies to bind $A \beta$ effectively in the periphery and thus exert the effect of a peripheral sink or by the inability to enter the brain and induce enhanced microglial uptake of $A \beta$. The observed increase of $A \beta_{42}$ concentrations in the brains of mice injected with antibodies $8 \mathrm{G} 7$ and $9 \mathrm{G} 10$, however, are in stark contrast to most published studies on the peripheral passive immunization with anti-A $\beta$ antibodies, suggesting that anti-A $\beta$ antibodies differ in their ability to reduce $A \beta_{42}$ levels when used in the same experimental setup. Similar increases in brain $A \beta$ levels after anti-A $\beta$ immunization, however, have been shown in other studies [32, 33], indicating again that a shift between $\mathrm{A} \beta$ levels of the CNS and periphery is bidirectional and the net effect depends on the antibody used and on the mode of antibody application.

In the present study we show that the bioactivity of anti-A $\beta$ antibodies depended on the epitope recognized. More importantly, the ability of an anti-A $\beta$ antibody to mediate $A \beta_{42}$ uptake by primary microglial cells can predict its bioactivity to reduce the brain levels of $A \beta_{42}$ in vivo. The collected data establish a framework for the evaluation and identification of in vivo active antibodies. In this respect, our data will help to design further experiments aiming at the refinement of amyloid-lowering strategies in vivo.

\section{Acknowledgments}

We thank Dr. Karen K. Hsiao (University of Minnesota, Minneapolis, Minn.) for providing SwAPP mice, Evotec Neurosciences for providing the anti-A $\beta$ hybridoma clones and Dr. Yoshinori Imai (National Institute of Science, Tokyo) for providing the Iba1 antibody. This work was funded partially by the Swiss National Science Foundation, the Stammbach Foundation, NCCR on Neural Plasticity and Regeneration, and the European Union under the programme 'Quality of Life and Management of Living Resources', Key Action 3 ‘The Cell Factory', Contract No. QLK3-CT-2001-02362.

\section{References}

1 Selkoe DJ: Alzheimer's disease results from the cerebral accumulation and cytotoxicity of amyloid beta-protein. J Alzheimers Dis 2001;3:7580

2 Selkoe DJ: Translating cell biology into therapeutic advances in Alzheimer's disease. Nature 1999;399(6738 suppl):A23-A31.

3 Hardy J, Selkoe DJ: The amyloid hypothesis of Alzheimer's disease: Progress and problems on the road to therapeutics. Science 2002;297. 353-356.

$>4$ Lewis J, et al: Enhanced neurofibrillary degeneration in transgenic mice expressing mutan tau and APP. Science 2001;293:1487-1491.

$>5$ Gotz J, et al: Formation of neurofibrillary tangles in P3011 tau transgenic mice induced by Abeta 42 fibrils. Science 2001;293:1491-1495.

6 Nicoll JA, et al: Neuropathology of human Alzheimer disease after immunization with amyloid-beta peptide: A case report. Nat Med 2003;9:448-452.

7 DeMattos RB, et al: Peripheral anti-Abeta antibody alters CNS and plasma Abeta clearance and decreases brain Abeta burden in a mouse model of Alzheimer's disease. Proc Natl Acad Sci USA 2001;98:8850-8855.
8 Bard F, et al: Peripherally administered antibodies against amyloid beta-peptide enter the central nervous system and reduce pathology in a mouse model of Alzheimer disease. Nat Med 2000;6:916-919.

$\checkmark 9$ Schenk D, et al: Immunization with amyloidbeta attenuates Alzheimer-disease-like pathology in the PDAPP mouse. Nature 1999;400: 173-177.

10 Mohajeri $\mathrm{MH}$, et al: Passive immunization against beta-amyloid peptide protects central nervous system (CNS) neurons from increased vulnerability associated with an Alzheimer's disease-causing mutation. J Biol Chem 2002; 277:33012-33017.

11 Morgan D, et al: Abeta peptide vaccination prevents memory loss in an animal model of Alzheimer's disease. Nature 2000;408:982985 .

12 Janus C, et al: Abeta peptide immunization reduces behavioural impairment and plaques in a model of Alzheimer's disease. Nature 2000;408:979-982.

13 Hock C, et al: Antibodies against beta-amyloid slow cognitive decline in Alzheimer's disease. Neuron 2003;38:547-554.

14 Bacskai BJ, et al: Imaging of amyloid-beta deposits in brains of living mice permits direct observation of clearance of plaques with immunotherapy. Nat Med 2001;7:369-372.
15 Frenkel D, Katz O, Solomon B: Immunization against Alzheimer's beta-amyloid plaques via EFRH phage administration. Proc Natl Acad Sci USA 2000;97:11455-11459.

16 Bacskai BJ, et al: Non-Fc-mediated mechanisms are involved in clearance of amyloidbeta in vivo by immunotherapy. $\mathrm{J}$ Neurosci 2002;22:7873-7878.

17 Pfeifer M, et al: Cerebral hemorrhage after passive anti-Abeta immunotherapy. Science 2002; 298:1379.

18 Furlan R, et al: Vaccination with amyloid-beta peptide induces autoimmune encephalomyelitis in C57/BL6 mice. Brain 2003;126:285291.

19 Schenk D: Amyloid-beta immunotherapy for Alzheimer's disease: The end of the beginning. Nat Rev Neurosci 2002;3:824-828.

20 Leverone JF, et al: Abeta1-15 is less immunogenic than Abeta 1-40/42 for intranasal immunization of wild-type mice but may be effective for 'boosting'. Vaccine 2003;21:2206-2215.

21 Lemere CA, et al: Intranasal immunotherapy for the treatment of Alzheimer's disease: Escherichia coli $\mathrm{LT}$ and LT(R192G) as mucosal adjuvants. Neurobiol Aging 2002;23:9911000 . 
22 Lemere CA, et al: Evidence for peripheral clearance of cerebral Abeta protein following chronic, active Abeta immunization in PSAPP mice. Neurobiol Dis 2003;14:10-18.

23 Mohajeri MH, Wollmer MA, Nitsch RM: Abeta 42-induced increase in neprilysin is associated with prevention of amyloid plaque formation in vivo. J Biol Chem 2002;277:35460 35465.

24 Ohsawa K, et al: Involvement of Ibal in membrane ruffling and phagocytosis of macrophages/microglia. J Cell Sci 2000;113:30733084.

25 Imai Y, et al: A novel gene ibal in the major histocompatibility complex class III region encoding an EF hand protein expressed in a monocytic lineage. Biochem Biophys Res Commun 1996;224:855-862.
26 Shibata M, et al: Clearance of Alzheimer's amyloid-ss(1-40) peptide from brain by LDL receptor-related protein-1 at the blood-brain barrier. J Clin Invest 2000;106:1489-1499.

27 Brazil MI, Chung H, Maxfield FR: Effects of incorporation of immunoglobulin $\mathrm{G}$ and complement component $\mathrm{Clq}$ on uptake and degradation of Alzheimer's disease amyloid fibrils by microglia. J Biol Chem 2000;275:1694116947.

28 Paresce DM, Ghosh RN, Maxfield FR: Microglial cells internalize aggregates of the Alzheimer's disease amyloid beta-protein via a scavenger receptor. Neuron 1996;17:553-565.

29 Wilcock DM, et al: Passive amyloid immunotherapy clears amyloid and transiently activates microglia in a transgenic mouse model of amyloid deposition. J Neurosci 2004;24:61446151.
30 Wang J, et al: The levels of soluble versus insoluble brain Abeta distinguish Alzheimer's disease from normal and pathologic aging. Exp Neurol 1999;158:328-337.

31 Naslund J, et al: Correlation between elevated levels of amyloid beta-peptide in the brain and cognitive decline. JAMA 2000;283:15711577.

32 Koller MF, et al: Immunization of mice with an $\mathrm{A} \beta \mathrm{Hsp} 70$ vaccine elicits anti-A $\beta$ antibodies and increased cerebral $A \beta$-levels. Neurodeg Dis 2004;1:20-28.

33 Vehmas AK, et al: beta-Amyloid peptide vaccination results in marked changes in serum and brain Abeta levels in APPswe/PS1DeltaE9 mice, as detected by SELDI-TOF-based ProteinChip technology. DNA Cell Biol 2001;20: 713-721. 